\title{
Feeding of Oligosarcus hepsetus (Cuvier, 1829) (Characiformes) in the Serra do Mar State Park - Santa Virgínia Unit, São Paulo, Brazil
}

\author{
Botelho, MLLA., Gomiero, LM.* and Braga, FMS. \\ Departamento de Zoologia, Instituto de Biociências, Universidade Estadual Paulista - UNESP, \\ Av. 24-A, n. 1515, CP 199, CEP 13506-900, Rio Claro, São Paulo, Brazil \\ *e-mail: leanmg@rc.unesp.br \\ Received February 2, 2006 - Accepted November 7, 2006 - Distributed November 30, 2007
}

(With 8 figures)

\begin{abstract}
We describe the diet of Oligosarcus hepsetus, in the Santa Virgínia Unit of the Serra do Mar State Park. The Paraibuna and Grande rivers in the basin of the Paraíba do Sul River were sampled monthly from January to December 2004. The Alimentary Preference Degree and the frequency of occurrence indices were used to analyze the food items. The diets of Oligosarcus hepsetus in the two localities sampled were very similar, and reinforced the importance of the streamside forests in establishing and maintaining biotic and abiotic conditions in these environments. The species had a carnivorous diet that differed with ontogeny: smaller individuals were principally insectivorous and larger ones ichthyophagous.
\end{abstract}

Keywords: Oligosarcus hepsetus, feeding, Atlantic Forest, Brazil.

\section{Alimentação de Oligosarcus hepsetus (Cuvier, 1829) (Characiformes) no Parque Estadual da Serra do Mar - Núcleo Santa Virgínia, São Paulo, Brasil}

\begin{abstract}
Resumo
O objetivo do trabalho foi abordar a dieta do peixe cachorro-magro, Oligosarcus hepsetus, no Núcleo Santa Virgínia do Parque Estadual da Serra do Mar. O rio Paraibuna e o ribeirão Grande da bacia do rio Paraíba do Sul foram amostrados mensalmente de janeiro a dezembro de 2004, sendo utilizados o Grau de Preferência Alimentar e a frequiência de ocorrência para as análises dos itens alimentares de Oligosarcus hepsetus. A dieta nos dois locais amostrados foi muito similar e ressaltou-se a importância das matas ribeirinhas para o fornecimento e a manutenção das condições bióticas e abióticas destes ambientes. A espécie apresentou dieta carnívora com diferenciação ontogenética, sendo que os indivíduos menores foram principalmente insetívoros e os maiores ictiófagos.
\end{abstract}

Palavras-chave: Oligosarcus hepsetus, alimentação, Floresta Atlântica, Brasil.

\section{Introduction}

Among the innumerable units composing the Leste basin in Brazil, the basin of the Paraíba do Sul River stands out (Braga, 2004). This isolated basin extends over an area of $57,000 \mathrm{~km}^{2}$ including three states in southeastern Brazil: São Paulo, Minas Gerais and Rio de Janeiro (Hilsdorf et al., 2002). The region has changed over time, through the influence of human activities carried out with a lack of appropriate conservation management. This has led to the felling of gallery forests, silting, water pollution, and innumerable other environmental problems, including those stemming from the construction of a number of reservoirs for electrical energy generation and/or water storage, among these the Paraibuna-Paraitinga and Funil dams (Hilsdorf and Petrere Jr., 2002). For these reasons, the state of conservation and composition of the ichthyofauna of the reservoirs has received some attention (Araújo, 1996;
Bizerril, 1999; Araújo et al., 2001; Hilsdorf and Petrere, 2002). However, the smaller affluents that descend the slopes of the Serra do Mar and Mantiqueira ranges are still little studied (Braga, 2004).

According to Villani et al. (1998), the state of São Paulo possesses the largest area of the Atlantic Forest and associated coastal ecosystems in the country, representing approximately $7 \%$ of its original plant cover. A large proportion of these remnants is located in state parks, ecological stations, and experimental stations, which cover more than $3 \%$ of the state's territory. In the Santa Virgínia Unit of the Serra do Mar State Park, some fish species (Brycon opalinus (Cuvier, 1819), Neoplecostomus microps (Steindachner, 1876) and Phalloceros caudimaculatus (Hensel, 1868)) were sampled in 1996; nevertheless, the fishes are the least- 
known vertebrates of the Atlantic Forest (Rosa and Menezes, 1996).

Fishes with a carnivorous feeding habit increase the stability of an ecosystem, being that they act to regulate the abundance of prey species (Nikolsky, 1963; Popova, 1978). Studies of trophic ecology of carnivorous species are very useful in monitoring fishery and management programs, given that these studies furnish important information on regulatory mechanisms in populations and communities of fishes (Zavala-Camin, 1996).

Fishes of the genus Oligosarcus have a large buccal aperture, permitting the ingestion of whole prey in a single bite (Casatti et al., 2001). Most species of this genus feed mainly on insects, crustaceans and small fish (Lowe-McConnell, 1975). The cachorro-magro, Oligosarcus hepsetus, is a small to medium-sized carnivore, occurring widely in most of the freshwater ecosystems in southeastern Brazil. It mainly inhabits shallow, densely vegetated microhabitats in small streams or along the banks of larger rivers (Araújo et al., 2005).

Notable seasonal changes may occur in the diet of fishes according to the area, primarily related to changes in composition and availability of food resources, associated with reproductive pulses and physical and chemical changes in the aquatic ecosystems. Diet may also be influenced by ontogenetic effects, which are generally related to morphological differences, which lead to changes in the selection and capture of prey species (Nikolsky, 1963; Wooton, 1992). Furthermore, knowledge of the diet of fishes provides essential information for ecological research, which also furnishes additional data on the entire trophic structure of the ecosystem (Basile-Martins et al., 1983).

The objective of the present study was to describe the diet of the fish "cachorro-magro," Oligosarcus hepsetus, in the Santa Virgínia Unit of the Serra do Mar State Park.

\section{Material and Methods}

We established two collection localities within the basin of the Paraíba do Sul River: the Paraibuna and Grande rivers, both within the Santa Virgínia Unit. This Unit covers 16,000 ha in the municipalities of São Luiz do Paraitinga, Natividade da Serra, Cunha and Ubatuba, located at coordinates $23^{\circ} 24^{\prime}$ and $23^{\circ} 17^{\prime} \mathrm{S}$ and $45^{\circ} 03^{\prime} \mathrm{W}$. The relief is steeply sloped, with rectilinear valleys and hogbacks with altitudes between 860 and $1,500 \mathrm{~m}$. The vegetation is dense montane ombrophile forest with discontinuous patches of forest in the process of regeneration, in addition to areas of abandoned eucalyptus plantations with a sub-wood of native plants. The climate is humid, subject to the Atlantic Tropical air mass (Villani et al., 1998).

A total of 12 samples were made monthly from January to December 2004. At each sample point, individuals were collected using gill nets with mesh sizes of $1.5 ; 2.0 ; 2.5 ; 3.0 ; 3.5$, and $4.0 \mathrm{~cm}$, measured between adjacent knots (10 $\mathrm{m}$ long and $1.5 \mathrm{~m}$ high), and totalizing
$60 \mathrm{~m}$. In addition to the nets, sieves, and traps were also used. Fish effort was standardized, keeping time and the quantity of instruments employed at each point constant. The gill nets were submerged from the end of the day up to the next morning.

Afterwards, specimens were kept in plastic containers containing $10 \%$ formalin. Each container received a label describing date and sample site.

Total length of individuals were measured in $\mathrm{cm}$, mass was measured in grams, repletion degree of the stomach, fat degree in the visceral cavity. Three categories, according to a previously established scale, indicated the repletion and fat degrees: 1 . empty, 2. half-full, and 3. full (Braga, 1990). The frequencies of the repletion degree of the stomach and of the fat degree in the visceral cavity were used to characterize the feeding of Oligosarcus hepsetus per collection period.

The stomachs with degree 3 (full) were withdrawn from the visceral cavity, weighed, and kept in alcohol diluted at 70\% (Zavala-Camin, 1996). Food items were identified with stereomicroscopic up to the lowest taxonomic level reached. To analyze the alimentary items found, the Alimentary Preference Degree (APD), was used following Braga (1999) in accordance with the formula: $\mathrm{APD}=\mathrm{Si} / \mathrm{N}$, where $\mathrm{Si}$ is the sum of the values related to abundance of the food item (i) in the stomachs and $\mathrm{N}$, the total number of the stomachs analyzed. The estimated value for the Alimentary Preference Degree (APD) for each item is indicated by:

$\mathrm{APD}=4$ : the chosen item has absolute preference;

$3 \leq \mathrm{APD}<4$ : the chosen item has high preference degree;

$2 \leq \mathrm{APD}<3$ : the chosen item is preferential, otherwise different items are ingested;

$1 \leq \mathrm{APD}<2$ : the chosen item is secondary; and

$0<\mathrm{APD}<1$ : the chosen item is occasional.

First, a general analysis of the food items was done, and then the Alimentary Preference Degree was analyzed for the remaining items, separated into the categories of allochthonous and autochthonous.

The method of Frequency of Occurrence (Hyslop, 1980) was also used, which is the percentage between the number of stomachs with preys from a determined taxonomic group and the total number of stomachs with food. This method was used to characterize the food by locality and by total-length class of Oligosarcus hepsetus.

Comparisons of diets between sites (Paraibuna and Grande) were made by the non-parametric statistic,

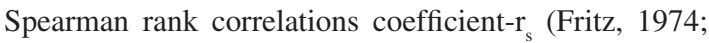
Siegel, 1975). Comparisons of diets between autochthonous items and allochthonous items were made by the non-parametric statistic, Mann-Whitney U proof (Siegel, 1975). With the objective of verifying the variation of alimentary items as fish and other categories with the length of the fish, an analysis was applied using a contingency table (Vanzolini, 1993). 


\section{Results}

A total of 162 specimens of Oligosarcus hepsetus, ranging in length from 8.5 to $25.0 \mathrm{~cm}$, were collected. The species was more common in the Grande River than in the Paraibuna River (Figure 1).

The distributions of relative frequencies of the repletion degree of the stomach, by collection, indicated that in January through August and in December, most of the individuals collected had degree 1 . At the end of winter and in spring, individuals more often had a repletion degree of 2 and 3. This tendency was obvious in the Grande River, although not in the Paraibuna River (Figure 2).

The distributions of the relative frequencies of the fat degree in the visceral cavity, by collection, showed that the highest number of individuals with degree of accumulated fat 3 occurred in October. This was the case in both the Paraibuna River and in the Grande River (Figure 3).

Analysis of the frequency of occurrence of the food items showed that Insect remains predominated, followed by Coleoptera, representing $35 \%$ of the items, and Fish at $22.5 \%$, followed in decreasing order by Orthoptera, Oligochaeta, Hemiptera, Dermaptera, Arachnida and Macrophytes, each of which represented $2.5 \%$ of the items found. In the Paraibuna River, the most important item was also Insect remains (50\%), followed by Coleoptera and Diptera, both representing approximately $40 \%$. In the Grande River, the most important item was Insect remains (approximately 50\%), followed by Coleoptera and Ephemeroptera, approximately $35 \%$ and $25 \%$, respectively (Figure 4).

A " $t$ " test on the $r_{s} 0.18$ indicates that the correlation is not significant $\left(\mathrm{t}=0.75 ; \mathrm{t}_{0.05 ; 17}=2.11 ; \mathrm{p}>0.05\right)$. Thus the diets of the fishes in both sites are quantitatively different.

The U Mann-Whitney proof applied to the ingested autochthonous items and allochthonous items, indicates that the result is significant $\left(\mathrm{U}=109>\mathrm{U}_{0.05: 17,14}=67\right)$; therefore, a difference exists in the ingestion of items.

For the autochthonous items, Odonata nymphs was the most important (17.5\%), followed by Scales (15\%),

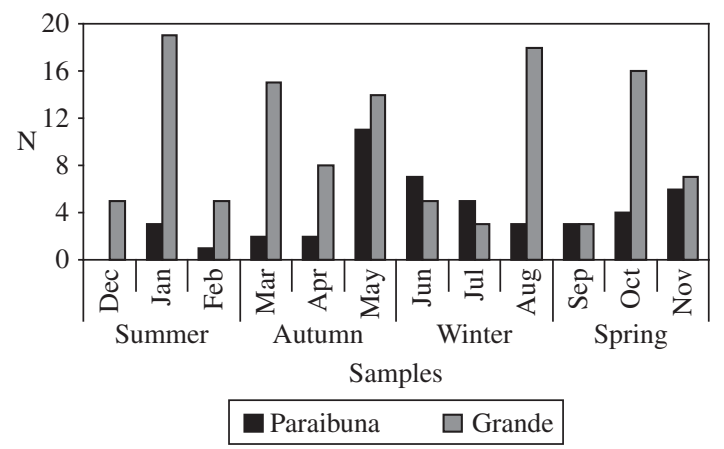

Figure 1. Numerical distribution of the individuals of Oligosarcus hepsetus in the collection localities. and in descending order Macrophytes, CrustaceanGammaridean, Dipteran pupa, Astyanax sp., Trychoptera and Trychopteran larva, each of which represented $2.5 \%$ of the items found. For the allochthonous items, the most important was Insect remains (50\%). In second place was Coleoptera (20\%), and in decreasing order Arachnida, Dermaptera, Adult Diptera, Gerridae, Odonata-Anisoptera, Oligochaeta, Orthoptera and adult Trychoptera, each representing $2.5 \%$ of the items found. In the Paraibuna River, the autochthonous item with the highest percentage was Dipteran larva (35\%), followed by Odonata nymphs $(25 \%)$. The most commonly occurring allochthonous item was Insect remains (50\%), closely followed by Coleopteran larva (25\%). In the Grande River, the most frequent autochthonous items were Odonata nymph, Scales and Nematoda, each representing $15 \%$ of the items sampled. The most frequent allochthonous item was Insect remains (50\%), closely followed by Coleoptera (approximately 25\%) (Figure 5).

The Alimentary Preference Degree (APD) showed that the most important item was Adult Ephemeroptera
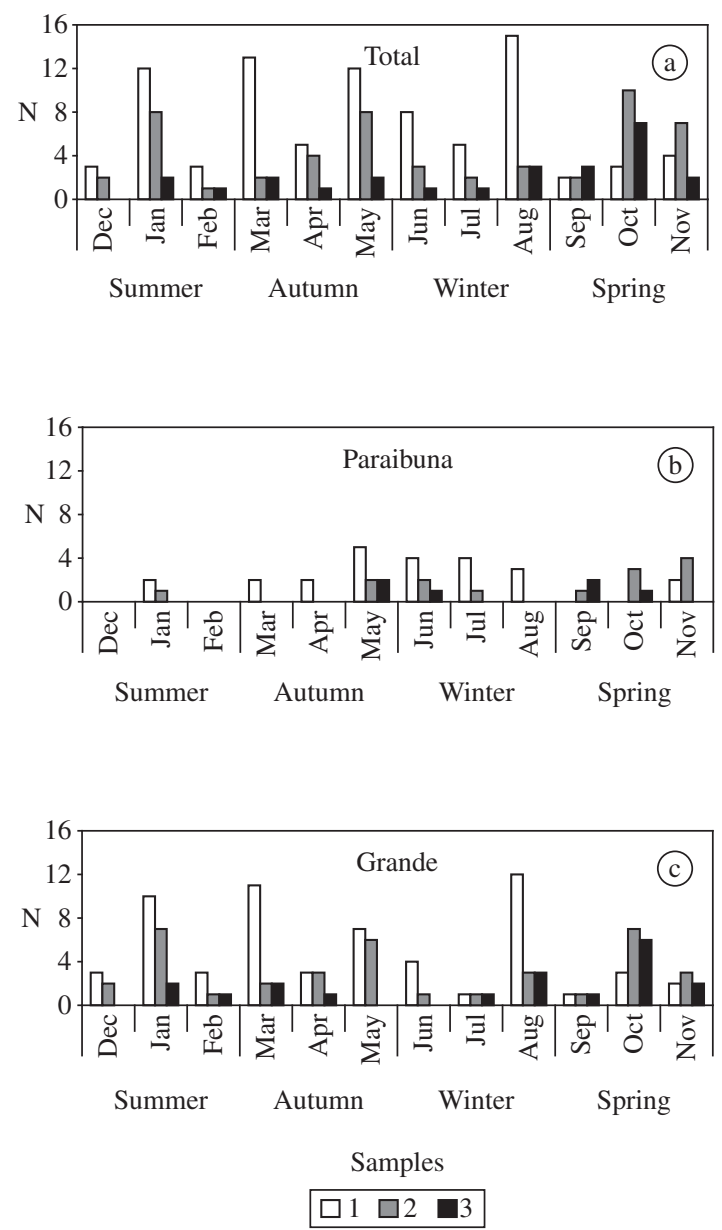

Figure 2. Numerical distribution of the repletion degree of the stomach (1. empty, 2. partly full, 3. full) of Oligosarcus hepsetus per collection and in each sampling locality. 

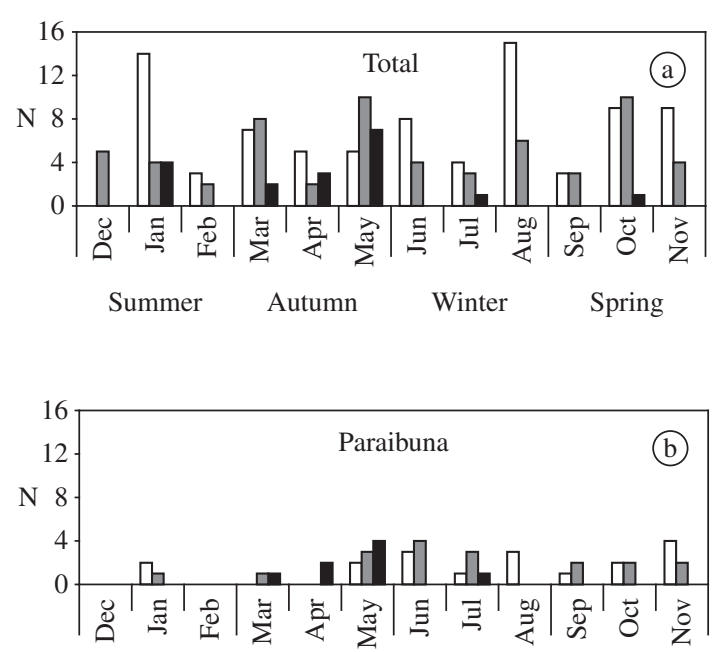

Summer Autumn Winter Spring

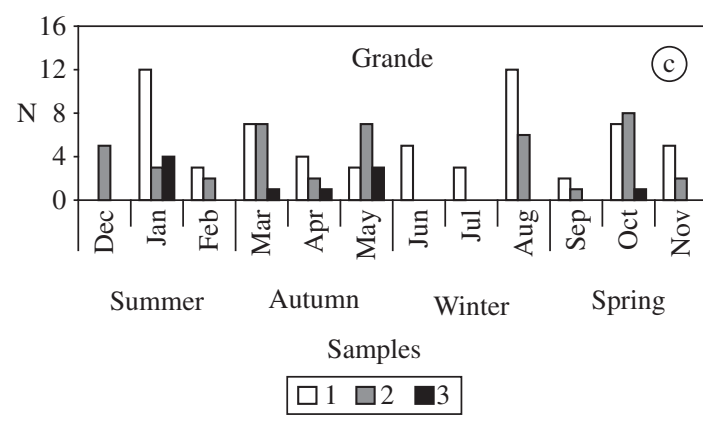

Figure 3. Numerical distribution of the fat degree in the visceral cavity (1. empty, 2. partly full, 3. full) of Oligosarcus hepsetus per collection and in each sampling locality.

with a degree of 0.7 (occasional), followed by Insect remains. For the prey fish species, Brycon opalinus showed an APD equal to 0.5 (occasional), decreasing to Phalloceros caudimaculatus and Astyanax sp., equally the least important. All the food items analyzed for Alimentary Preference Degree were occasional (Figure 6).

When food items were grouped into categories, the most important was Insects (nymphs and pupas), with a APD of 1.6 (secondary), followed by Adult Insects with APD approximately 1.5 (secondary), decreasing to the item Sediments, with a value close to zero (occasional) (Figure 7).

In the smaller total-length classes (5 to $10 \mathrm{~cm}$ ), the items Fish and Scales were consumed less (35\%) than were other items $(67 \%)$. As the total-length classes increased, consumption of Fish also increased, until in the largest total-length class (20 to $25 \mathrm{~cm}$ ), only this item appeared in the food of Oligosarcus hepsetus (Figure 8).

A preference for the item fish with the length increase in $O$. hepsetus was influenced strongly in the test
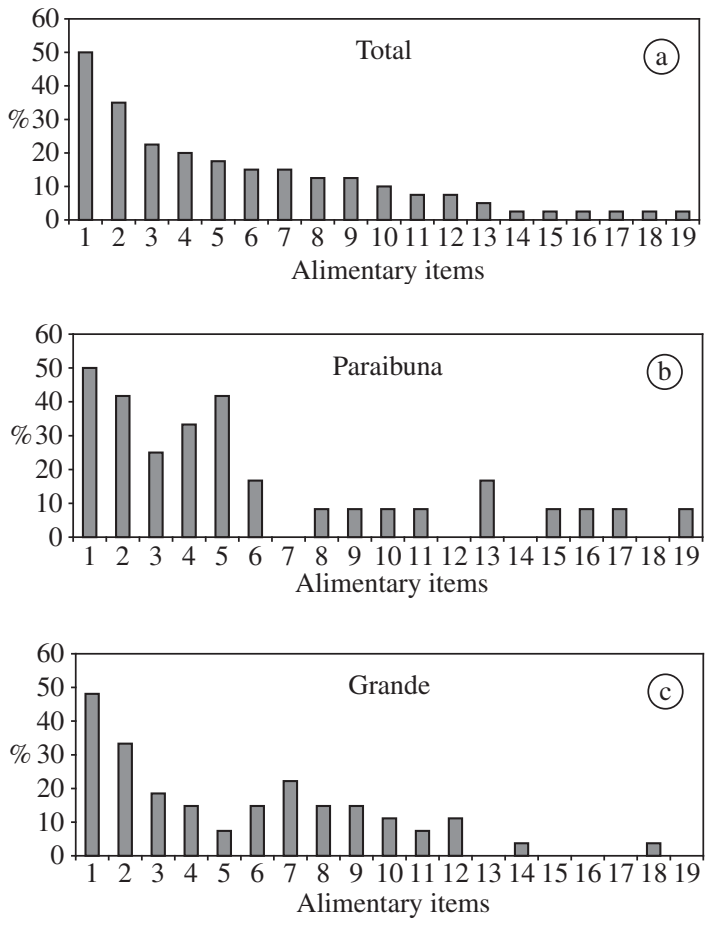

Figure 4. Frequency of occurrence of the food items of Oligosarcus hepsetus in the Santa Virgínia Unit, for the Paraibuna and Grande rivers, were: 1) Insect remains; 2) Coleoptera; 3) Fish; 4) Odonata; 5) Diptera; 6) Scales; 7) Ephemeroptera; 8) Trychoptera; 9) Nematoda; 10) Crustacea; 11) Vegetal remains; 12) Hymenoptera; 13) Sediments; 14) Orthoptera; 15) Oligochaeta; 16) Hemiptera; 17) Dermaptera; 18) Arachnida and 19) Macrophytes.

by the absence of others items in the total-length class ( 20 to $25 \mathrm{~cm}$ ).

\section{Discussion}

According to Nikolsky (1963), the low feeding activity of piscivorous fishes is expected and can be explained by the better use and nutritional value of the food, which makes it necessary to feed less often. A high incidence of empty stomachs of many carnivorousichthyophagous species was also found by Goulding (1980), Cruz et al. (1990) and Bennemann et al. (1996). Although Oligosarcus hepsetus showed this characteristic, a large number of individuals had full stomachs in spring. This may have occurred because of the increased temperature and rainfall, which increase the input of insects and organic matter into the river, thus making larger amounts of food items available to the fish, as happened with Oligosarcus jenynsii in Lake Caconde, Rio Grande do Sul state (Hartz et al., 1996).

Another important fact was the large proportion of individuals with degree 3 of accumulated fat in the autumn, when food is scarce. Lowe-McConnell (1964), 

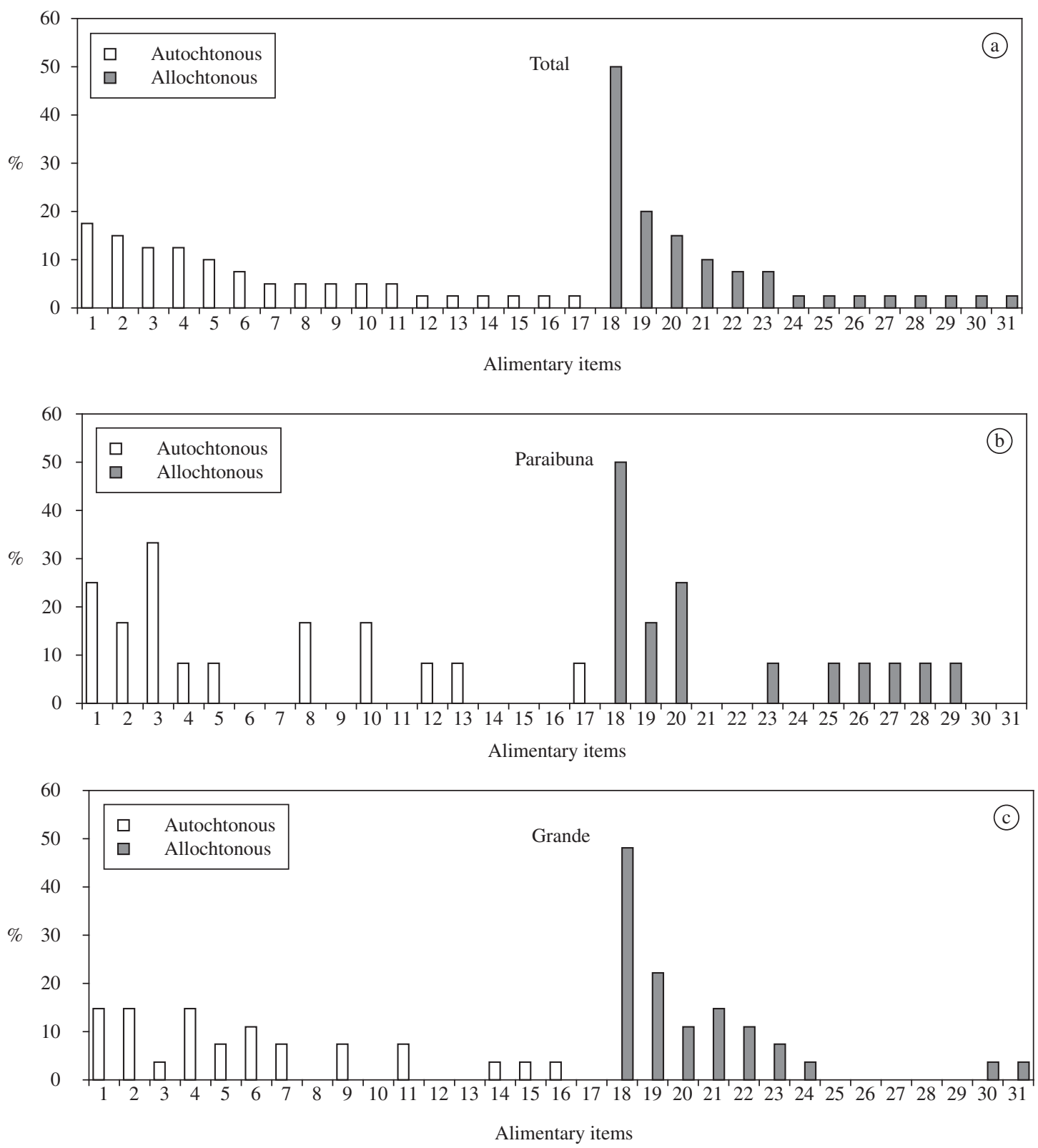

Figure 5. Frequency of occurrence of the autochthonous and allochthonous food items of Oligosarcus hepsetus in the Santa Virgínia Unit, for the Paraibuna and Grande rivers. (Autochthonous items: 1) Odonata nymphs; 2) Scales; 3) Dipteran larva; 4) Nematoda; 5) Fish; 6) Macrobrachium potiuna; 7) Ephemeropteran larva; 8) Phalloceros caudimaculatus; 9) Brycon opalinus; 10) Sediments; 11) Trychopteran pupa; 12) Macrophytes; 13) Crustacean-Gammaridean; 14) Dipteran pupa; 15) Astyanax sp.; 16) Trychoptera; 17) Trychopteran larva. Allochthonous items: 18) Insect remains; 19) Coleoptera; 20) Coleopteran larva; 21) Ephemeroptera; 22) Formicidae; 23) Vegetal remains; 24) Arachnida; 25) Dermaptera 26) Adult Diptera; 27) Gerridae; 28) Odonata-Anisoptera; 29) Oligochaeta; 30) Orthoptera and 31) Adult Trychoptera).

Goulding (1980) and Mérona and Mérona (2004) established that many species feed less in the dry season and consume the fat accumulated during the rainy season. Thus, Oligosarcus hepsetus apparently feeds more frequently in the spring and summer, storing a large fat reserve that will be used in autumn and winter as a source of energy for survival and gonad development. This behavior was observed by Bennemann et al. (1996) for
Acestrorhyncus lacustris, which was actively reproducing in the area studied (Tibagi River, Paraná state), and for which the sequence of events of increased feeding activity, fat storage, and then breeding could be established.

The richness of food items was very similar between the two collection localities, although food items occurred more frequently in the Paraibuna than in the 


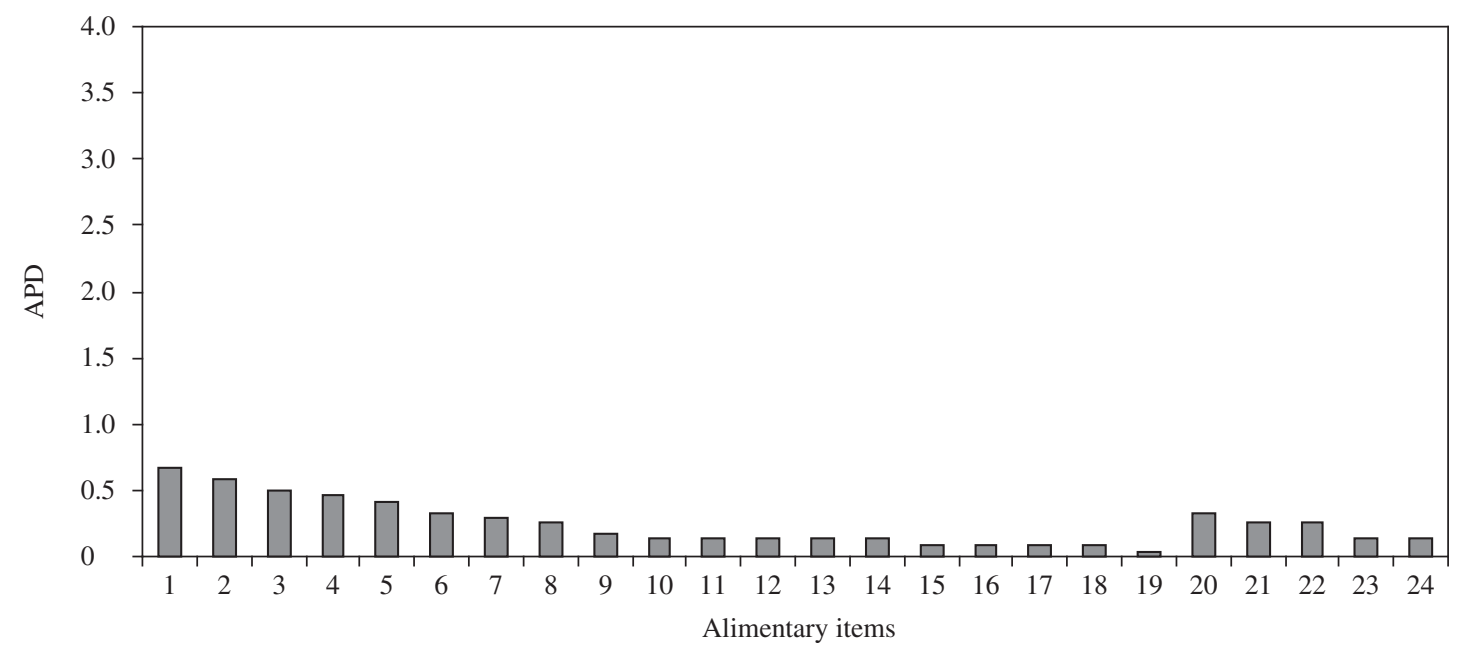

Figure 6. Alimentary Preference Degree (APD) of Oligosarcus hepsetus in the Santa Virgínia Unit, were: 1) Ephemeroptera; 2) Insect remains; 3) Odonata nymphs; 4) Machrobrachium potiuna; 5) Coleoptera; 6) Coleopteran larva; 7) Dipteran larva; 8) Trychopteran pupa; 9) Dipteran pupa; 10) Orthoptera; 11) Crustacean-Gammaridean; 12) Oligochaeta; 13) Macrophytes; 14) Nematoda; 15) Odonata-Anisoptera; 16) Vegetal remains; 17) Adult Trychoptera; 18) Adult Formicidae; 19) Sediments; 20) Brycon opalinus; 21) Fish remains; 22) Scales; 23) Phalloceros caudimaculatus and 24) Astyanax sp.

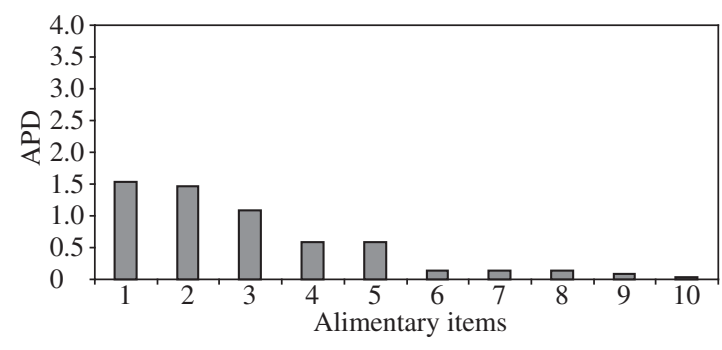

Figure 7. Alimentary Preference Degree(APD) of Oligosarcus hepsetus in the Santa Virgínia Unit, were: 1) Insects (nymphs and pupas); 2) Insects (adults); 3) Fish; 4) Crustacea; 5) Insect remains; 6) Oligochaeta; 7) Macrophytes; 8) Nematoda; 9) Vegetal remains; 10) Sediments.

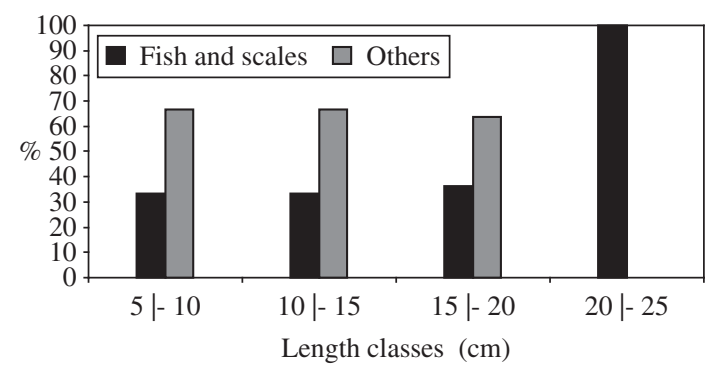

Figure 8. Frequency of occurrence of the food items consumed by Oligosarcus hepsetus, distributed by total-length classes.

Grande River. This difference between the two localities can be explained by the larger size and greater vegetation cover in the Paraibuna River, as well as the lower abundance of Oligosarcus hepsetus, which may lessen intraspecific competition. This was also observed by Alvim and Peret (2004), who concluded that the occurrence of autochthonous as much as allochthonous food items is dependent on the gallery forest, hence the importance of conserving the riverine forest to maintain the ecological balance of a river. From the point of view of the biology of the fish, the gallery forest has the following ecological functions: structural protection of the habitats, regulation of water flow and discharge, shelter and shade, maintenance of water quality, filtration of substances that arrive in the river, and providing organic matter and substrates for fixation of algae and periphyton (Barrella et al., 2001). Lowe-McConnell (1987) observed that rivers bordered by native vegetation provide a wide variety of food items, mainly insects and higher plants. These items are of great importance for the survival and ecology of freshwater tropical fishes.

The Alimentary Preference Degree for the items consumed by Oligosarcus hepsetus showed that the items were occasional, and when these were grouped, the first three items were secondary: Insects (nymphs and pupas); Insects (adults) and Fish. This result was confirmed by Araújo et al. (2005) in Lajes Reservoir, where Oligosarcus hepsetus showed a carnivorous feeding habit, feeding only on insects and fish and varying its diet according to the seasons and the zones of the reservoir.

In Oligosarcus hepsetus the difference in feeding during ontogeny was evident, in that smaller individuals were basically insectivorous and larger ones ichthyophagous. Hahn et al. (2000) found only fish in the stomachs of individuals of Acestrorhyncus lacustris over $10 \mathrm{~cm}$ long in the Itaipu Reservoir. Araújo et al. (2005) observed a similar situation, in which Oligosarcus hepsetus larger than $19 \mathrm{~cm}$ fed principally on fish, in contrast to smaller individuals which fed principally on insects. Similarly, Gealh and Hahn (1998) found for Oligosarcus longirostris in the Segredo Reservoir, that smaller individuals fed on insects, crustaceans and fish, whereas larger ones $(>16 \mathrm{~cm})$ were exclusively piscivorous. Araújo 
et al. (2005) reported that larger Oligosarcus hepsetus were apparently able to capture higher-quality prey, i.e., which was larger, heavier and probably richer in energy. The increase in size is related to morphological changes (size of buccal aperture and swimming speed) that may facilitate catching fish. Ontogenetic changes in feeding may also be associated with a decrease in intraspecific competition, with smaller individuals feeding preferentially on insects, and larger ones consuming mainly fish (Lowe-McConnell, 1987).

Acknowledgments - The authors wish to thank FAPESP (proc. 03/05696-1) for financial support, Cotec (proc. 40.673/03), IBAMA (aut. 055/2003), Mc. J. P. Villani (Director of the Santa Virgínia Unit) for making it possible to carry out this research, and to Dr. Edilberto Gianotti for help in identifying the food items.

\section{References}

ALVIM, MCC. and PERET, AC., 2004. Food resources sustaining the fish fauna in a section of the upper São Francisco River in Três Marias, MG, Brazil. Braz. J. Biol, São Carlos, vol. 64 , no. 2, p. 3-15.

ARAÚJO, FG., 1996. Composição e estrutura da comunidade de peixes do médio e baixo rio Paraíba do Sul, RJ. Rev. Bras. Biol., vol. 56 , no. 1, p. 111-126.

ARAÚJO, F G., FICHBERG, I., PINTO, BCT. and PEIXOTO, MG., 2001. Variações espaciais na assembléia de peixes do rio Paraíba do Sul (Barra Mansa, Barra do Piraí), Rio de Janeiro, Brasil. Rev. Bras. Zool., Curitiba, vol. 18, no. 2, p. 483-492.

ARAÚJO, FG., ANDRADE, CC., SANTOS, RN., SANTOS AFGN. and SANTOS, LN., 2005. Spatial and seasonal changes in the diet of Oligosarcus hepsetus (Characiformes, Characidae) in a brazilian reservoir. Rev. Bras. Zool., vol. 65, no. 1, p. 1-8.

BARRELlA, W., PETRERE JR., M., SMITH, WS. and MONTAG, LFA., 2001. As relações entre as matas ciliares, os rios e os peixes. In Matas ciliares: Conservação e Recuperação. RODRIGUES, RR. and LEITÃO FILHO, HF. $2^{\mathrm{a}}$ Edição. São Paulo: EDUSP, 320p.

BASILE-MARTINS, MA., CIPÓLI, MN. and GODINHO, HM., 1983. Alimentação do mandi Pimelodus maculatus Lacépède, 1803 (Osteichthyes, Pimelodidae) de trechos dos rios Jaguari e Piracicaba, São Paulo, Brasil. Bol. Inst. Pesca., vol. 13 , no. 1 , p. 17-19.

BENNEMANN, ST., ORSI, ML. and SHIBATTA, O., 1996. A Atividade alimentar de espécies de peixe do rio Tibagi, relacionada com o desenvolvimento de gordura e das gônadas. Rev. Bras. Biol., vol. 13, no. 2, p. 501-512.

BIZERRIL, CRSF., 1999. A ictiofauna da bacia do rio Paraíba do Sul. Biodiversidade e padrões biogeográficos. Arch. Biol. Tech., Curitiba, vol. 42, no. 2, p. 233-250.

BRAGA, FMS., 1990. Aspectos da reprodução e alimentação de peixes comuns em um trecho do rio Tocantins entre Imperatriz e Estreito, Estados do Maranhão e Tocantins, Brasil. Rev. Bras. Biol., vol. 50, no. 3, p. 547-558.

-, 1999. O grau de preferência alimentar: um método qualitativo e quantitativo para o estudo do conteúdo estomacal de peixes. Acta Scientarium, vol. 21, no. 2, p. 291-295.
-, 2004. Habitat, distribuição e aspectos adaptativos de peixes da microbacia do ribeirão Grande, estado de São Paulo, Brasil. Acta Scientarium, vol. 26, no. 1, p. 31-36.

CASATTI, L., LANGEANI, F. and CASTRO, RMC., 2001. Peixes de riacho do Parque Estadual Morro do Diabo, bacia do Alto Rio Paraná, SP. Rev. Biota Neotropica, vol. 1, no. 1, p. 1-15.

CRUZ, JA., MOREIRA, JA., VERANI, JR., GIRARDI, L. and TORLONI, CEC., 1990. Levantamento da ictiofauna e aspectos da dinâmica de população de algumas espécies do reservatório de Promissão, SP ( $1^{\text {a }}$ etapa). São Carlos, SP, CESP/UFSCAR, $78 \mathrm{p}$.

FRITZ, ES., 1974. Total diet comparison in fishes by Spearman rank correlation coefficients. Copeia, 1974, no. 1, p. 210-214.

GEALH, AM. and HAHN, NS., 1998. Alimentação de Oligosarcus longirostris do reservatório de Salto Segredo, Paraná, Brasil. Rev. Bras. Zool., vol. 15, no. 4, p. 985-993.

GOULDING, M., 1980. The fishes and forest: exploration in Amazonian Natural History. Berkeley: University of California Press, 280p.

HAHN, NS., DELARIVA, RL. and LOUREIRO, VE., 2000. Feeding of Acestrorhyncus lacustris (Characidae): a Post Impoundment Studies on Itaipu Reservoir, Upper Paraná River, PR. Braz. Arch. Biol. Tech., vol. 43, no. 2, p. 207-213.

HARTZ, SM., MARTINS, A. and BARBIERI, G., 1996. Dinâmica da alimentação e dieta de Oligosarcus jenynsii (Günther, 1864) na lagoa Caconde, Rio Grande do Sul, Brasil (TEleOSTEI, CHARACIDAE). Bol. Inst. Pesca, São Paulo, vol. 23, no. único, p. 21-29.

HILSDORF, AWS., AZEREDO-ESPIN, AML., KRIEGER, MH. and KRIEGER, JE., 2002. Mitocondrial DNA diversity in wild and cultured populations of Brycon opalinus from the Paraíba do Sul basin, Brazil. Aquaculture, vol. 214, no. 1-4, p. 81-91.

HILSDORF, AWS. and PETRERE JR., M., 2002. Conservação de peixes na bacia do rio Paraíba do Sul. Ciência Hoje, vol. 30, no. 180 , p. $62-65$.

HYSLOP, EJ., 1980. Stomach contents analysis. A review of methods and their application. Journal of Fish Biology, vol. 17, no. 4 , p. 411-29.

LOWE-MCCONNELL, RHL., 1964. The fishes of the Rupununi savanna district of British Guiana, South America. Part I. Ecological groupings of fish species and effects of the seazonal cycle on the fish. Journal of the Linnean Society (Zoology), vol. 45, no. 304, p. 103-144.

-, 1975. Fish communities in tropical freshwaters. Longman, London, 337p.

-, 1987. Ecological studies in tropical fish communities. Cambridge Univ. Press. Cambridge, 382p.

MÉRONA, B. and MÉRONA, JR., 2004. Food resource partitioning in a fish community of the central Amazon floodplain. Neotropical Ichthyology, vol. 2, no. 2, p. 75-84.

NIKOLSKY, GV., 1963. The ecology of fishes. London: Academic Press, 352p.

POPOVA, OA., 1978. The role of predaceous fish in ecosystems. Ed. GERKING, SD. Blackwell Scientific, Oxford: p. 215-249.

ROSA, RS. and MENEZES, NA., 1996. Relação preliminar das espécies de peixes (Pisces, Elasmobranchii, Actinopterygii) ameaçadas no Brasil. Rev. Bras. Zool., vol. 13, no. 3, p. 647-667. 
SIEGEL, S., 1975. Estatística não-paramétrica. Para as ciências do comportamento. Rio de Janeiro, McGraw-Hill do Brasil, 350p.

VANZOLINI, PE., 1993. Métodos estatísticos elementares em sistemática zoológica. Ed. HUCITEC., 130p.

VILLANI, JP., SANCHES, RA. and MARETTI, CC., 1998. Plano de manejo das unidades de conservação: Parque Estadual da Serra do Mar - Núcleo Santa Virgínia: Plano de Gestão
Ambiental- Fase 1. Secretaria do Meio Ambiente, Estado de São Paulo, São Paulo, 128p.

WOOTON, RJ., 1992. Fish ecology. New York: Chapman and Hall, 212p.

ZAVALA-CAMIN, LA., 1996. Introdução aos estudos sobre alimentação natural em peixes. Maringá-PR: Eduem/Nupelia, 129p. 